\title{
PENERAPAN ANALISIS JALUR DALAM MENGANALISIS MODEL HUBUNGAN KAUSALITAS ANTARA DIMENSI RELATIONSHIP MARKETING DENGAN LOYALITAS PELANGGAN
}

\author{
Sri Sustarliyah \\ Teknik Manajemen Industri Universitas Langlangbuana Bandung \\ sustarliyah.lppm@yahoo.co.id
}

\begin{abstract}
Abstrak
Teknik analisis jalur dikembangkan oleh Sewal Wright di tahun 1934, sebenarnya merupakan pengembangan korelasi yang diurai menjadi beberapa interpretasi akibat yang ditimbulkannya. Lebih lanjut, analisis jalur mempunyai kedekatan dengan regresi berganda; atau dengan kata lain, regresi berganda merupakan bentuk khusus dari analisis jalur.Teknik ini juga dikenal sebagai model sebab-akibat (causing modeling).Asumsi dasar model ini ialah beberapa variabel sebenarnya mempunyai hubungan yang sangat dekat satu dengan lainnya. Dalam Analisis jalur dapat diketahui derajat hubungan antara variabel dependen, pengaruh langsung, pengaruh tidak langsung, total pengaruh dan pengaruh gabungan (simultan) serta pengujian hipotesis yang diukur secara parsial dan simultan. Pada penelitian ini penyelesaian analisis jalur menggunakan bantuan software SPSS Versi 20.0. Hasil dari analisis jalur tersebut membuktikan bahwa dimensi-dimensi relationship marketing (trust, bonding, communication, empathy, shared value dan Reciprocity) yang dinilai memiliki pengaruh positif dan signifikan terhadap loyalitas pelanggan adalah dimensi trust, bonding, shared value dan emphaty, sementara untuk dimensi communication dan Reciprocity dinlai tidak signifikan dalam analisis jalur.
\end{abstract}

Kata Kunci :trust, bonding, communication, empathy, shared value dan Reciprocity dan Loyalitas

\section{PENDAHULUAN}

Hotel merupakan suatu bentuk bangunan, lambang, perusahaan atau badan usaha akomodasi yang menyediakan pelayanan jasa penginapan, penyedia makanan dan minuman serta fasilitas jasa lainnya dimana semua pelayanan itu diperuntukkan bagi masyarakat umum yang bermalam maupun mereka yang hanya menggunakan fasilitas tertentu yang dimiliki hotel tersebut.Pada dekade saat ini, persaingan dalam bisnis hotel semakin pesat dan meningkat.Oleh karena itu, pihak manajemen harus berorientasi pada pelanggan.Artinya, kedekatan dengan pelanggan perlu dijaga atau bahkan ditingkatkan. Salah satu cara yang baik dalam kedekatan dengan pelanggan dapat dijalin melalui relationship marketing. Menurut Kotler dan Amstrong (2012:173) proses relationship marketing merupakan faktor penting dalam keputusan pembelian tamu bisnis untuk melakukan pembelian berulang terus-menerus (loyal). Dalam hal ini relationship marketing

merupakan faktor penting dalam mencapai loyalitas. Sebagaimana diperkuat kembali oleh Griffin (2009:3) bahwa "CustomerLoyalty adalah orang-orang yang melakukan pembelian secara teratur, membeli antar lini produk dan jasa, mereferensikannya kepada orang lain, dan menjunjukkan kekebalan terhadap tarikan dari pesaing".

Menara Peninsula Hotel membuat Klub Rumpi sebagai program kedekatan dengan pelanggan yaitu memberikan beberapa keuntungan bagi membernya terutama bagi member bisnis.Hal ini karena pada umumnya member bisnis melakukan booking kamar lebih dari 10 kamar setiap satu kali booking. Menurut Sin et al. (2006:409), Relationship Marketing adalah kegiatan hubungan bisnis pemasaran yang merupakan strategi untuk menarik pelanggan, membangun hubungan jangka panjang dan loyalitas. Relationship Marketing terdiri dari trust, bonding, communication, 
shared value, empathy, dan reciprocity.Relationship Marketing merupakan salah satu strategi dalam bidang pemasaran yang saat ini semakin banyak diimplementasikan oleh perusahaan-perusahaan di Indonesia. Berdasarkan latar belakang di atas maka peneliti ingin meneliti mengenai :'Pengaruh Relationship MarketingTerhadap Loyalitas Pelanggan Menara Peninsula Hotel" (Survei pada Member Bisnis Klub Rumpi yang menginap di Menara Peninsula Hotel). Berdasarkan latar belakang di atas maka dapat dirumuskan permasalahan yaitu pengaruh Relationship Marketing terhadap loyalitas pelanggandi Menara Peninsula Hotel

\section{KAJIAN PUSAKA DAN KERANGKA BERPIKIR}

Hotel merupakan sarana akomodasi komersial yang menyediakan berbagai fasilitas produk dan jasa untuk memenuhi kebutuhan tamu. Dalam melaksanakan aktivitasnya, suatu hotel membutuhkan proses pemasaran. Kotler dan Keller (2012:17) menyatakan bahwa pemasaran adalah proses mengidentifikasi dan menemukan kebutuhan manusia dan sosial. Pendekatan pemasaran difokuskan pada konsep pemasaran holistik yang terdiri dari : internal marketing, integrated marketing, performance marketing dan relationship marketing. Ekspektasi pelanggan dari waktu ke waktu yang semakin tinggi membuat pemasar berpikir dan mulai cara untuk memenuhi kebutuhan pelanggan. Berdasarkan Tjiptono (2011:513) seiring perkembangan kompetisi global, suatu perusahaan perlu memiliki kegiatan pendekatan atau strategi agar dapat menyelaraskan kompetisi, teknologi dan sumber daya sesuai dengan kebutuhan dan keinginan pelanggan yang dinamis.Oleh karena itu, mengingat peran pelanggan semakin tinggi, bagi suatu perusahaan dirasakan perlu untuk menjalin hubungan lebih intim dan berkelanjutan dalam jangka panjang.Salah satu kegiatan pendekatan atau strategi tersebut adalah relationship marketing..

Strategi relationship marketing meliputi hal menciptakan, mempertahankan dan mendorong hubungan erat dengan pelanggan.Semakin lama pemasaran semakin bergeser dari berfokus pada transaksi individual kearah berfokus pada menjalin hubungan bernilai tinggi membangun hubungan lebih berorientasi jangka panjang.Sasarannya adalah memberikan nilai jangka panjang kepada pelanggan dan ukuran suksesnya adalah kepuasan pelanggan jangka panjang.Menurut Sin et al. (2006:409), Relationship Marketing adalah kegiatan hubungan bisnis pemasaran yang merupakan strategi untuk menarik pelanggan, membangun hubungan jangka panjang dan loyalitas. Relationship Marketing terdiri dari trust, bonding, communication, shared value, empathy, dan reciprocity. Tjiptono (2011:439) menyatakan bahwa Relationship Marketing yang kokoh dan saling menguntungkan antara perusahaan dengan pelanggan dapat membangun bisnis ulangan (repeat business), sehingga meningkatkan loyalitas.Barnes (2003:41) menyatakan bahwa aspek penting yang membuat pelanggan loyal adalah adanya hubungan pemasaran (Relationship Marketing).

Hubungan pemasaran yang menciptakan ikatan emosional membuat pelanggan menjadi loyal dan mendorong mereka untuk terus berbisnis, melakukan pembelian ulang terhadap pemasaran serta akan merekomendasikan hal baik. Dalam relationship marketing, loyalitas adalah tujuan utama perusahaan, kekuatan hubungan pelanggan dengan perusahaan salah satunya ditunjukkan dari tingkat kepuasan pelanggan (Storkacks dan Lethinen, 2003:83).

\section{METODE PENELITIAN}

Sugiyono (2013:1) menyatakan bahwa "Metode penelitian pada dasarnya merupakan cara ilmiah untuk mendapatkan data dengan tujuan dan kegunaan tertentu". Berdasarkan variabel-variabel yang diteliti, maka jenis penelitian ini adalah penelitian deskriptif dan verifikatif. Menurut pendapat Sugiyono (2010:35) penelitian deskriptif sebagai berikut:Penelitian deskriptif adalah penelitian yang dilakukan untuk mengetahui keberadaan varibel mandiri baik satu variabel atau lebih (variabel yang berdiri sendiri) tanpa membuat perbandingan dan/atau mencari hubungan variabel satu sama lain.

Penelitian deskriptif bertujuan untuk memperoleh gambaran mengenai relationship marketing dan loyalitas member Klub Rumpi di Menara Peninsula Hotel.Sedangkan penelitian verifikatif menurut Mashuri (2008:45) sebagai berikut: "Penelitian verifikatif adalah metode untuk menguji kebenaran, memeriksa benar tidaknya apabila dijelaskan untuk menguji suatu cara dengan atau tanpa perbaikan yang telah 
dilaksakan di tempat lain dengan mengatasi masal yang serupa dengan kehidupan.”Dalam hal ini penelitian verifikatif bertujuan untuk mengetahui pengaruh relationship marketingterhadap loyalitas pelanggan.Berdasarkan jenis penelitian di atas, maka metode penelitian yang digunakan adalah metode explanatory survey. Menurut Sugiyono (2010:11) "metode survey adalah metode penelitian yang dilakukan pada populasi besar maupun kecil, tetapi data yang dipelajari adalah data dari sampel yang diambil dari populasi tersebut, sehingga ditemukan kejadian-kejadian relatif, distribusi, dan hubungan-hubungan antar variabel sosiologis maupun psikologis."Dalam penelitian ini yang menjadi populasi sasarannya adalah tamu yang terdaftar sebagai member
Klub Rumpi di Menara Peninsula Hotel. Jumlah member Klub Rumpi sampai dengan akhir tahun 2013 berjumlah 466 member. Teknik sampling menggunakan rumus slovin dan penyebaran sampel secara random sampling. Hasil dari perhitungan rumus sampling diperoleh sampel minimal pada penelitian ini sebanyak 71 orang.

\section{HASIL ANALISIS}

Berdasarkan prinsip-prinsip dasar di atas, maka alur model hubungan yang dibangun dan analisis jalur yang digunakan, terlebih dahulu diperlihatkan gambar mengenai pengaruh struktural dan koefisien jalur keseluruhan variabel sebagai berikut.

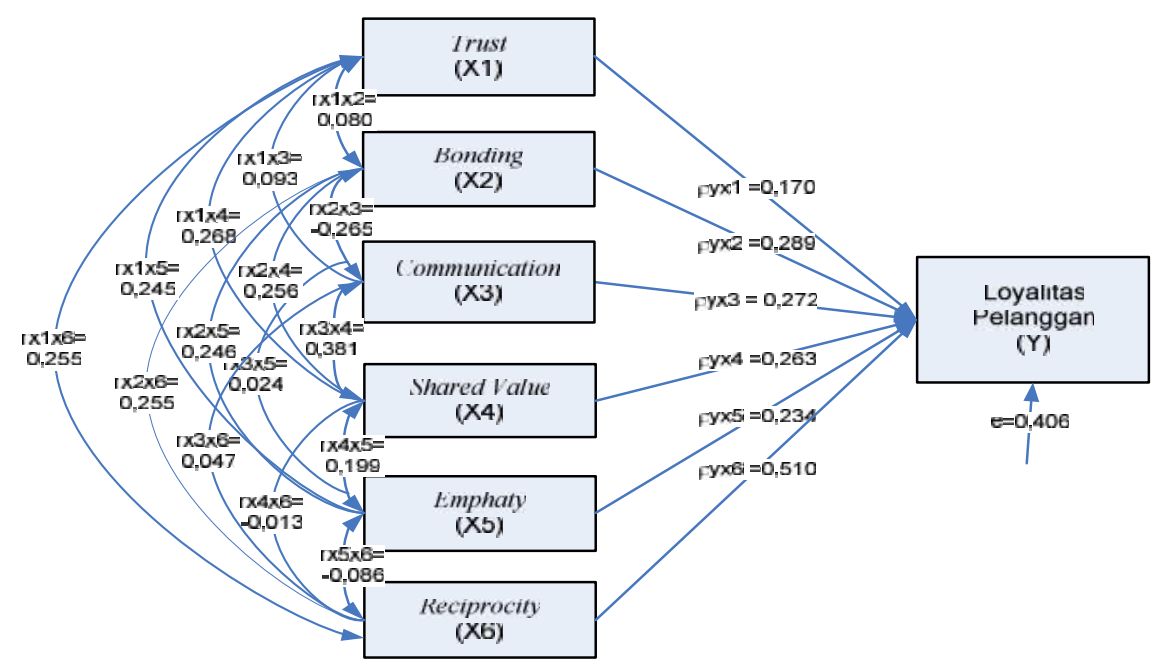

Gambar 1 Model Struktur 1 dalam Analisis Jalur (Path Analysis)

Sumber : Data diolah, 2015

Berdasarkan Gambar 1 tentang model analisis dapat diperoleh persamaan analisis jalur, sebagai berikut :

$$
\begin{aligned}
& \mathrm{Y}=0,347 \rho \mathrm{yx} 1+0,238 \rho \mathrm{y} 2+ \\
& 0,150 \rho y x 3+0,332 \rho y x 4+0,353 \rho y x 5+0,080 \\
& \text { рух6+0,382e. }
\end{aligned}
$$

Keterangan :

$$
\begin{aligned}
& \text { pyx1 = koefisien jalur antara } \mathrm{X}_{1} \text { dengan } \mathrm{Y} \\
& \text { sebesar } 0,347 \\
& \text { pyx2 }=\text { koefisien jalur antara } \mathrm{X}_{2} \text { dengan } \mathrm{Y} \\
& \text { sebesar } 0,238 \\
& \text { pyx3 = koefisien jalur antara } \mathrm{X}_{3} \text { dengan } \mathrm{Y} \\
& \text { sebesar } 0,150
\end{aligned}
$$

pyx4 = koefisien jalur antara $\mathrm{X}_{4}$ dengan $\mathrm{Y}$ sebesar 0,332

pyx5 = koefisien jalur antara $\mathrm{X}_{5}$ dengan $\mathrm{Y}$ sebesar 0,353

pyx5 = koefisien jalur antara $\mathrm{X}_{6}$ dengan $\mathrm{Y}$ sebesar 0,080

$\mathrm{e}=$ epsilon sebesar 0,273

\section{A. Hubungan Antara Variabel}

Terdapat dugaan yang menyatakan bahwa terdapat hubungan yangpositifantara faktorfaktor : efektivitas pengelolaan dana bos dan peran komite sekolah. Hubungan diantarakedua variabel bebas tersebut dapat dilihat pada gambar berikut. 


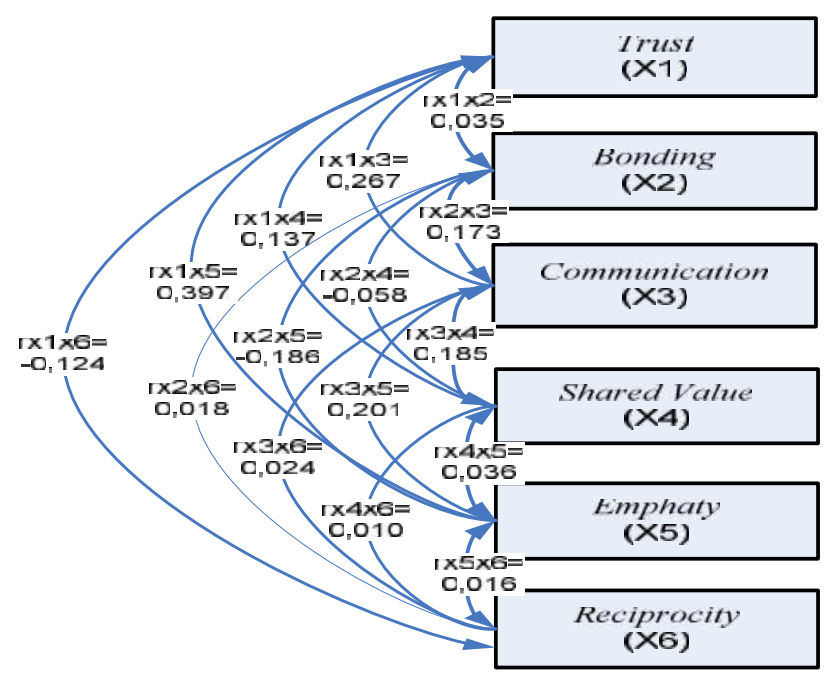

\section{Gambar 2. Hubungan Antara Dimensi Trust, Bonding, Communication, Shared Value, Emphaty dan Reciprocity \\ Sumber : Data diolah, 2015}

Kriteria keeratan hubungan antara variabel mengacu pada pendapat yang dikemukakan oleh Sevilla et.al. (1997: 280), yang menyatakan bahwa "high or low correlation, dependens generally on the nature of variables being studied. You may, how ever the following categorization which most specialists in statistics usually agree with". Secara rinci keeratan kriteria korelasi dapat dilihat pada Tabel berikut.

Tabel 1 Tabel Korelasi

\begin{tabular}{|c|c|}
\hline Correlation (r) & Indication \\
\hline $\begin{array}{l}\text { Between } \pm, 80 \text { to } \\
1,00 \\
\text { Between } \pm, 60 \text { to }, 79 \\
\text { Between } \pm, 40 \text { to }, 59 \\
\text { Between } \pm, 20 \text { to }, 39 \\
\text { Between } \pm, 01 \text { to }, 19\end{array}$ & $\begin{array}{l}\text { High correlation ( Sangat tinggi ) } \\
\text { Moderately high correlation ( Tinggi ) } \\
\text { Moderately correlation ( Sedang ) } \\
\text { Low correlation ( Rendah ) } \\
\text { Negligible correlation ( Sangat rendah ) }\end{array}$ \\
\hline
\end{tabular}

Sumber : Sudjana, 2003

1. Hubungan variabel antara Trust $\left(\mathrm{X}_{1}\right)$, dengan Bonding $\left(\mathrm{X}_{2}\right)$, diperoleh nilai koefisien korelasi yang sebesar 0,035 . Dengan demikian, dapat dikatakan bahwa hubungan kedua variabel tersebut di atas mempunyai hubungan yang positif dengan kriteria keeratan hubungan Negligible correlation (Sangat rendah).

2. Hubungan variabel antaraTrust $\left(\mathrm{X}_{1}\right)$, dengan Communication $\left(\mathrm{X}_{3}\right)$, diperoleh nilai koefisien korelasi yang sebesar 0,267. Dengan demikian, dapat dikatakan bahwa hubungan kedua variabel tersebut di atas mempunyai hubungan yang positif dengan kriteria keeratan hubungan Low correlation ( Rendah ).

3. Hubungan variabel antaraTrust $\left(\mathrm{X}_{1}\right)$, dengan Shared value $\left(\mathrm{X}_{4}\right)$, diperoleh nilai koefisien korelasi yang sebesar 0,137. Dengan demikian, dapat dikatakan bahwa hubungan kedua variabel tersebut di atas mempunyai hubungan yang positif dengan kriteria keeratan hubungan Negligible correlation (Sangat rendah).

4. Hubungan variabel antaraTrust $\left(\mathrm{X}_{1}\right)$, dengan emphaty $\left(\mathrm{X}_{5}\right)$, diperoleh nilai koefisien korelasi yang sebesar 0,397. Dengan demikian, dapat dikatakan bahwa hubungan kedua variabel tersebut di atas 
mempunyai hubungan yang negatif dengan kriteria keeratan hubungan Negligible correlation( Sangat rendah ).

5. Hubungan variabel antaraTrust $\left(\mathrm{X}_{1}\right)$, dengan reciprocity $\left(\mathrm{X}_{6}\right)$, diperoleh nilai koefisien korelasi yang sebesar $-0,124$. Dengan demikian, dapat dikatakan bahwa hubungan kedua variabel tersebut di atas mempunyai hubungan yang positif dengan kriteria keeratan hubungan Negligible correlation (Sangat rendah).

6. Hubungan variabel antara Bonding $\left(\mathrm{X}_{2}\right)$, dengan Communication $\left(\mathrm{X}_{3}\right)$, diperoleh nilai koefisien korelasi yang sebesar 0,173. Dengan demikian, dapat dikatakan bahwa hubungan kedua variabel tersebut di atas mempunyai hubungan yang positif dengan kriteria keeratan hubungan Negligible correlation ( Sangat rendah ).

7. Hubungan variabel antara Bonding $\left(\mathrm{X}_{2}\right)$, dengan Shared value $\left(\mathrm{X}_{4}\right)$, diperoleh nilai koefisien korelasi yang sebesar $-0,058$. Dengan demikian, dapat dikatakan bahwa hubungan kedua variabel tersebut di atas mempunyai hubungan yang negatif dengan kriteria keeratan hubungan Negligible correlation ( Sangat rendah).

8. Hubungan variabel antara Bonding $\left(\mathrm{X}_{2}\right)$, dengan empathy $\left(\mathrm{X}_{5}\right)$, diperoleh nilai koefisien korelasi yang sebesar $-0,186$. Dengan demikian, dapat dikatakan bahwa hubungan kedua variabel tersebut di atas mempunyai hubungan yang negatif dengan

13.diatas mempunyai hubungan yang positif dengan kriteria keeratan hubungan Negligible correlation ( Sangat rendah ).

14. Hubungan variabel antara Shared value $\left(\mathrm{X}_{4}\right)$, dengan emphaty $\left(\mathrm{X}_{5}\right)$, diperoleh nilai koefisien korelasi yang sebesar 0,036. Dengan demikian, dapat dikatakan bahwa hubungan kedua variabel tersebut di atas mempunyai hubungan yang positif dengan kriteria keeratan hubungan Negligible correlation ( Sangat rendah ).

15. Hubungan variabel antara Shared value $\left(\mathrm{X}_{4}\right)$, dengan reciprocity $\left(\mathrm{X}_{6}\right)$, diperoleh nilai koefisien korelasi yang sebesar 0,010. Dengan demikian, dapat dikatakan bahwa hubungan kedua variabel tersebut di atas mempunyai hubungan yang positif dengan kriteria keeratan hubungan Negligible correlation ( Sangat rendah). kriteria keeratan hubungan Negligible correlation ( Sangat rendah).

9. Hubungan variabel antara Bonding $\left(\mathrm{X}_{2}\right)$, dengan reciprocity $\left(\mathrm{X}_{6}\right)$, diperoleh nilai koefisien korelasi yang sebesar 0,018 . Dengan demikian, dapat dikatakan bahwa hubungan kedua variabel tersebut di atas mempunyai hubungan yang positif dengan kriteria keeratan hubungan Negligible correlation ( Sangat rendah ).

10.Hubungan variabel antara Communication $\left(\mathrm{X}_{3}\right)$, dengan shared value $\left(\mathrm{X}_{4}\right)$, diperoleh nilai koefisien korelasi yang sebesar 0,185. Dengan demikian, dapat dikatakan bahwa hubungan kedua variabel tersebut di atas mempunyai hubungan yang positif dengan kriteria keeratan hubungan Negligible correlation ( Sangat rendah ).

11.Hubungan variabel antara Communication $\left(\mathrm{X}_{3}\right)$, dengan shared value $\left(\mathrm{X}_{5}\right)$, diperoleh nilai koefisien korelasi yang sebesar 0,201. Dengan demikian, dapat dikatakan bahwa hubungan kedua variabel tersebut di atas mempunyai hubungan yang positif dengan kriteria keeratan hubungan Low correlation (Rendah).

12.Hubungan variabel antara Communication $\left(\mathrm{X}_{3}\right)$, dengan reciprocity $\left(\mathrm{X}_{6}\right)$, diperoleh nilai koefisien korelasi yang sebesar 0,024. Dengan demikian, dapat dikatakan bahwa hubungan kedua variabel tersebut

B. Analisis Kontribusi Pengaruh Variabel Relationship Marketing (Trust, Bonding, Communication, Shared value, empathy dan Reciprocity) terhadap Variabel Loyalitas Pelanggan secara parsial.

Analisis kontribusi pengaruh dalam analisis jalur terdiri dari analisis pengaruh secara langsung, tidak langsung dan total pengaruh yang kemudian digabungkan menjadi pengaruh simultan yang diberikan oleh variabel independen terhadap variabel dependen. Berikut ini diuraikan mengenai pengaruh dari masing-masing dimensi pada variabel relationship marketing terhadap loyalitas pelanggan.

\section{Analisis Pengaruh Dimensi Trust terhadap loyalitas pelanggan}

Adapun hasil analisis pengaruh dimensi trust terhadap loyalitas pelanggan baik secara 
langsung, tidak langsung maupun total dengan program SPSS Versi 20.0, dapat dilihat pengaruh secara parsial yang didasarkan pada sebagai berikut hasil analisis jalur dan dibantu perhitungannya

Tabel 2 Kontribusi Pengaruh Dimensi Trust $\left(\mathrm{X}_{1}\right)$ Terhadap Loyalitas Pelanggan (Y)

\begin{tabular}{|c|c|c|}
\hline Uraian & Perhitungan & $(\%)$ \\
\hline Pengaruh Langsung $\mathrm{X}_{1}$ Terhadap $\mathrm{Y}$ & $\left(\rho y \times 1^{2} .100 \%\right)$ & 12,04 \\
\hline Pengaruh tak Langsung $\mathrm{X}_{1}$ Melalui $\mathrm{X}_{2}$ Terhadap $\mathrm{Y}$ & $(\rho y x 1 . r x 1 x 2 . \rho y x 2.100 \%)$ & 0,29 \\
\hline Pengaruh tak Langsung $\mathrm{X}_{1}$ Melalui $\mathrm{X}_{3}$ Terhadap Y & $(\rho y x 1 . r x 1 x 3 . \rho y x 3.100 \%)$ & 1,39 \\
\hline Pengaruh tak Langsung $\mathrm{X}_{1}$ Melalui $\mathrm{X}_{4}$ Terhadap Y & $(\rho y x 1 . r x 1 x 4 . \rho y x 4.100 \%)$ & 1,58 \\
\hline Pengaruh tak Langsung $\mathrm{X}_{1}$ Melalui $\mathrm{X}_{5}$ Terhadap Y & $(\rho y x 1 . r x 1 \times 5 . \rho y x 5.100 \%)$ & 4,86 \\
\hline Pengaruh tak Langsung $\mathrm{X}_{1}$ Melalui $\mathrm{X}_{6}$ Terhadap Y & $(\rho y x 1 . r x 1 x 6 . \rho y x 6.100 \%)$ & $-0,34$ \\
\hline Total Pengaruh Tidak Langsung & & 7,78 \\
\hline Total Pengaruh $\mathrm{X}_{1}$ Terhadap Y & & 19,82 \\
\hline
\end{tabular}

Sumber :Hasil Perhitungan

Berdasarkan tabel di atas, diketahui bahwa pengaruh langsung dari dimensi trust sebesar $19,82 \%$, sedangkan total pengaruh tidak langsung baik melalui dimensi bonding, communication, shared value, empathy dan reciprocity sebesar $7,78 \%$, sehingga total pengaruh dari dimensi trust baik secara langsung maupun tidak langsung sebesar $19,82 \%$.

\section{Analisis Pengaruh Dimensi Bonding terhadap loyalitas pelanggan}

Adapun hasil analisis pengaruh dimensi bonding terhadap loyalitas pelanggan baik secara langsung, tidak langsung maupun total pengaruh secara parsial yang didasarkan pada hasil analisis jalur dan dibantu perhitungannya dengan program SPSS Versi 20.0, dapat dilihat sebagai berikut :

Tabel 3 Kontribusi Pengaruh Dimensi Bonding $\left(\mathrm{X}_{2}\right)$ Terhadap Loyalitas Pelanggan (Y)

\begin{tabular}{|c|c|c|}
\hline Uraian & Perhitungan & $(\%)$ \\
\hline Pengaruh Langsung $\mathrm{X}_{2}$ Terhadap $\mathrm{Y}$ & $\left(\rho y \times 2^{2} .100 \%\right)$ & 5,66 \\
\hline Pengaruh tak Langsung $\mathrm{X}_{2}$ Melalui $\mathrm{X}_{1}$ Terhadap $\mathrm{Y}$ & $(\rho y x 2 . r x 2 x 1 . \rho y x 1.100 \%)$ & 0,29 \\
\hline Pengaruh tak Langsung $\mathrm{X}_{2}$ Melalui $\mathrm{X}_{3}$ Terhadap Y & ( $\rho y x 2 . r x 2 x 3 . \rho y x 3.100 \%)$ & 0,62 \\
\hline Pengaruh tak Langsung $\mathrm{X}_{2}$ Melalui $\mathrm{X}_{4}$ Terhadap Y & $(\rho y x 2 . r x 2 \times 4 . \rho y x 4.100 \%)$ & $-0,46$ \\
\hline Pengaruh tak Langsung $\mathrm{X}_{2}$ Melalui $\mathrm{X}_{5}$ Terhadap Y & $(\rho y x 2 . r \times 2 \times 5 . \rho y x 5.100 \%)$ & $-0,98$ \\
\hline Pengaruh tak Langsung $\mathrm{X}_{2}$ Melalui $\mathrm{X}_{6}$ Terhadap Y & 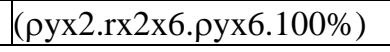 & $-0,23$ \\
\hline Total Pengaruh Tidak Langsung & & $-0,76$ \\
\hline Total Pengaruh $\mathrm{X}_{2}$ Terhadap Y & & 4,90 \\
\hline
\end{tabular}

Sumber :Hasil Perhitungan

Berdasarkan tabel di atas, diketahui bahwa pengaruh langsung dari dimensi bonding sebesar $5,66 \%$, sedangkan total pengaruh tidak langsung baik melalui dimensi trust, communication, shared value, empathy dan reciprocity sebesar $-0,76 \%$, sehingga total pengaruh dari dimensi trust baik secara langsung maupun tidak langsung sebesar $4,90 \%$. Negatifnya pengaruh tidak langsung diakibatkan karena pihak manajemen hotel kurang maksimal dalam mengkomunikasikan dengan pelanggan terkait jasa layanan hotel 
lainnya, kepercayaan yang dibangun untuk memperkuat loyalitas masih dinilai lemah dan lemahnya jaringan bisnis yang dibangun oleh pihak Peninsula dengan para pelanggan, sehingga hal inilah yang memperkecil pengaruh dari dimensi bonding (ikatan) terhadap loyalitas pelanggan.

\section{E. Analisis \\ Pengaruh communication terhadap pelanggan \\ Dimensi \\ loyalitas}

Tabel 4 Kontribusi Pengaruh Dimensi Communication $\left(\mathbf{X}_{3}\right)$ Terhadap Loyalitas Pelanggan (Y)

\begin{tabular}{|c|c|c|}
\hline Uraian & Perhitungan & $(\%)$ \\
\hline Pengaruh Langsung $\mathrm{X}_{3}$ Terhadap $\mathrm{Y}$ & $\left(\rho y x 3^{2} .100 \%\right)$ & 2,25 \\
\hline Pengaruh tak Langsung $X_{3}$ Melalui $X_{1}$ Terhadap $Y$ & 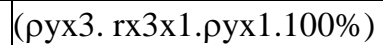 & 1,39 \\
\hline Pengaruh tak Langsung $\mathrm{X}_{3}$ Melalui $\mathrm{X}_{2}$ Terhadap $\mathrm{Y}$ & 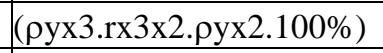 & 0,62 \\
\hline Pengaruh tak Langsung $\mathrm{X}_{3}$ Melalui $\mathrm{X}_{4}$ Terhadap $\mathrm{Y}$ & 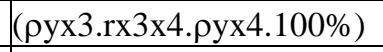 & 0,92 \\
\hline Pengaruh tak Langsung $\mathrm{X}_{3}$ Melalui $\mathrm{X}_{5}$ Terhadap $\mathrm{Y}$ & 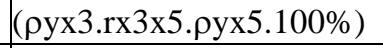 & 1,06 \\
\hline Pengaruh tak Langsung $\mathrm{X}_{3}$ Melalui $\mathrm{X}_{6}$ Terhadap $\mathrm{Y}$ &  & $-0,14$ \\
\hline Total Pengaruh Tidak Langsung & & 3,85 \\
\hline Total Pengaruh $\mathrm{X}_{3}$ Terhadap Y & & 6,10 \\
\hline
\end{tabular}

Sumber : Hasil Perhitungan

Berdasarkan tabel di atas, diketahui bahwa pengaruh langsung dari dimensi communication sebesar $3,85 \%$, sedangkan total pengaruh tidak langsung baik melalui dimensi trust, bonding, shared value, empathy dan reciprocity sebesar 3,85\%, sehingga total pengaruh dari dimensi communication baik secara langsung maupun tidak langsung sebesar $6,10 \%$.
Adapun hasil analisis pengaruh dimensi communication terhadap loyalitas pelanggan baik secara langsung, tidak langsung maupun total pengaruh secara parsial yang didasarkan pada hasil analisis jalur dan dibantu perhitungannya dengan program SPSS Versi 20.0, dapat dilihat sebagai berikut :

\section{F. Analisis Pengaruh Dimensi Shared Value terhadap loyalitas pelanggan}

Adapun hasil analisis pengaruh dimensi shared value terhadap loyalitas pelanggan baik secara langsung, tidak langsung maupun total pengaruh secara parsial yang didasarkan pada hasil analisis jalur dan dibantu perhitungannya dengan program SPSS Versi 20.0, dapat dilihat sebagai berikut :

Tabel 5 Kontribusi Pengaruh Dimensi Shared Value $\left(\mathrm{X}_{4}\right)$ Terhadap Loyalitas Pelanggan (Y)

\begin{tabular}{|c|c|c|}
\hline Uraian & Perhitungan & $(\%)$ \\
\hline Pengaruh Langsung $\mathrm{X}_{4}$ Terhadap Y & $\left(\rho y x 4^{2} .100 \%\right)$ & 11,022 \\
\hline Pengaruh tak Langsung $\mathrm{X}_{4}$ Melalui $\mathrm{X}_{1}$ Terhadap $\mathrm{Y}$ & $(\rho y x 4 . r x 4 x 1 . \rho y x 1.100 \%)$ & 1,58 \\
\hline Pengaruh tak Langsung $\mathrm{X}_{4}$ Melalui $\mathrm{X}_{2}$ Terhadap $\mathrm{Y}$ & (рух4.rx4x2.pyx2.100\%) & $-0,46$ \\
\hline Pengaruh tak Langsung $\mathrm{X}_{4}$ Melalui $\mathrm{X}_{3}$ Terhadap $\mathrm{Y}$ & $(\rho y x 4 . r x 4 x 3 . \rho y \times 3.100 \%)$ & 0,92 \\
\hline Pengaruh tak Langsung $\mathrm{X}_{4}$ Melalui $\mathrm{X}_{5}$ Terhadap $\mathrm{Y}$ & 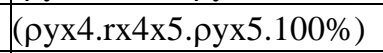 & 0,19 \\
\hline Pengaruh tak Langsung $\mathrm{X}_{4}$ Melalui $\mathrm{X}_{6}$ Terhadap $\mathrm{Y}$ & 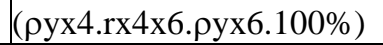 & 0,03 \\
\hline Total Pengaruh Tidak Langsung & & 2,26 \\
\hline Total Pengaruh $\mathrm{X}_{4}$ Terhadap Y & & 13,28 \\
\hline
\end{tabular}

Sumber :Hasil Perhitungan

Berdasarkan tabel di atas, diketahui bahwa pengaruh langsung dari dimensi shared value sebesar $11,022 \%$, sedangkan total pengaruh tidak langsung baik melalui dimensi trust, bonding, communication, empathy dan reciprocity sebesar $2,26 \%$, sehingga total pengaruh dari dimensi shared value baik 
secara langsung maupun tidak langsung sebesar 13,28\%.

\section{G. Analisis Pengaruh Dimensi Empathy terhadap loyalitas pelanggan}

Adapun hasil analisis pengaruh dimensi empathy terhadap loyalitas pelanggan baik secara langsung, tidak langsung maupun total pengaruh secara parsial yang didasarkan pada hasil analisis jalur dan dibantu perhitungannya dengan program SPSS Versi 20.0, dapat dilihat sebagai berikut:

Tabel 6 Kontribusi Pengaruh Dimensi Empathy $\left(\mathrm{X}_{5}\right)$ Terhadap Loyalitas Pelanggan (Y)

\begin{tabular}{|c|c|c|}
\hline Uraian & Perhitungan & $(\%)$ \\
\hline Pengaruh Langsung $\mathrm{X}_{5}$ Terhadap $\mathrm{Y}$ & $\left(\rho y x 5^{2} .100 \%\right)$ & 12,46 \\
\hline Pengaruh tak Langsung $\mathrm{X}_{5}$ Melalui $\mathrm{X}_{1}$ Terhadap Y & 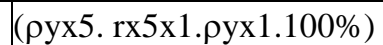 & 4,86 \\
\hline Pengaruh tak Langsung $\mathrm{X}_{5}$ Melalui $\mathrm{X}_{2}$ Terhadap $\mathrm{Y}$ & $(\rho y \times 5 . r x 5 \times 2 . \rho y \times 2.100 \%)$ & $-0,98$ \\
\hline Pengaruh tak Langsung $\mathrm{X}_{5}$ Melalui $\mathrm{X}_{3}$ Terhadap $\mathrm{Y}$ & $(\rho y x 5 . r x 5 \times 3 . \rho y x 3.100 \%)$ & 1,06 \\
\hline Pengaruh tak Langsung $\mathrm{X}_{5}$ Melalui $\mathrm{X}_{4}$ Terhadap $\mathrm{Y}$ & 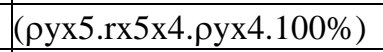 & 0,19 \\
\hline Pengaruh tak Langsung $\mathrm{X}_{5}$ Melalui $\mathrm{X}_{6}$ Terhadap $\mathrm{Y}$ & 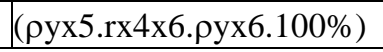 & 0,05 \\
\hline Total Pengaruh Tidak Langsung & & 5,18 \\
\hline Total Pengaruh $\mathrm{X}_{5}$ Terhadap Y & & 17,64 \\
\hline
\end{tabular}

Sumber :Hasil Perhitungan

Berdasarkan tabel di atas, diketahui bahwa pengaruh langsung dari dimensi empathy sebesar $12,46 \%$, sedangkan total pengaruh tidak langsung baik melalui dimensi trust, bonding, communication, shared value dan reciprocity sebesar $5,18 \%$, sehingga total pengaruh dari dimensi shared value baik secara langsung maupun tidak langsung sebesar $17,64 \%$.

\section{H. Analisis Pengaruh Dimensi Reciprocity terhadap loyalitas pelanggan}

Adapun hasil analisis pengaruh dimensi reciprocity terhadap loyalitas pelanggan baik secara langsung, tidak langsung maupun total pengaruh secara parsial yang didasarkan pada hasil analisis jalur dan dibantu perhitungannya dengan program SPSS Versi 20.0, dapat dilihat sebagai berikut

Tabel 7 Kontribusi Pengaruh Dimensi Reciprocity $\left(\mathrm{X}_{6}\right)$ Terhadap Loyalitas Pelanggan (Y)

\begin{tabular}{|c|c|c|}
\hline Uraian & Perhitungan & $(\%)$ \\
\hline Pengaruh Langsung $\mathrm{X}_{6}$ Terhadap $\mathrm{Y}$ & $\left(\rho y x 6^{2} .100 \%\right)$ & 0,64 \\
\hline Pengaruh tak Langsung $X_{6}$ Melalui $X_{1}$ Terhadap $Y$ & (рух6. rx6x1.pyx1.100\%) & $-0,34$ \\
\hline Pengaruh tak Langsung $\mathrm{X}_{6}$ Melalui $\mathrm{X}_{2}$ Terhadap $\mathrm{Y}$ & 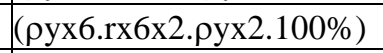 & $-0,23$ \\
\hline Pengaruh tak Langsung $\mathrm{X}_{6}$ Melalui $\mathrm{X}_{3}$ Terhadap $\mathrm{Y}$ & 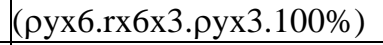 & $-0,14$ \\
\hline Pengaruh tak Langsung $X_{6}$ Melalui $X_{4}$ Terhadap $Y$ & 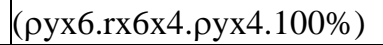 & 0,03 \\
\hline Pengaruh tak Langsung $\mathrm{X}_{6}$ Melalui $\mathrm{X}_{5}$ Terhadap $\mathrm{Y}$ & (рух6.rx6x5.pyx5.100\%) & 0,05 \\
\hline Total Pengaruh Tidak Langsung & & $-0,63$ \\
\hline Total Pengaruh $\mathrm{X}_{6}$ Terhadap $\mathrm{Y}$ & & 0,01 \\
\hline
\end{tabular}

Sumber :Hasil Perhitungan

Berdasarkan tabel di atas, diketahui bahwa pengaruh langsung dari dimensi reciprocity sebesar $0,64 \%$, sedangkan total pengaruh tidak langsung baik melalui dimensi trust, bonding, communication, empathydan shared value sebesar $-0,63 \%$, sehingga total pengaruh dari dimensi reciprocity baik secara langsung maupun tidak langsung sebesar
$0,01 \%$. Negatifnya pengaruh tidak langsung, hal ini disebabkan bahwa pihak manajemen hotel belum pernah memberikan tunjangan atau bantuan kepada para pelanggan baik berupa mendapat tiket gratis, cendera mata ataupun bentuk lainnya kepada pelanggan yang pernah melakukan penyewaan antara 1-3 kali di Peninsula Hotel, sehingga 
kontribusinya relatif kecil atau bahkan tidak ada sama sekali dari reciprocity terhadap loyalitas pelanggan.

\section{Analisis Pengaruh Relationship Marketing (trust, bonding, communication, shared value dan empathy) secara simultan terhadap loyalitas pelanggan.}

Analisis pengaruh Relationship Marketing (trust, bonding, communication, shared value dan empathy) secara simultan terhadap loyalitas pelanggan berdasarkan hasil analisis jalur (path analysis), dapat dijelaskan bahwa total pengaruh secara simultan dari keenam dimensi (trust, bonding, communication, shared value dan empathy) terhadap loyalitas pelanggan sebesar $61,80 \%$, sedangkan sisa pengaruh (epsilon ) sebesar 38,20\% yang tidak dijelaskan pada penelitian ini.

\section{KEISMPULAN}

Hasil dari analisis jalur tersebut membuktikan bahwa dimensi-dimensi relationship marketing (trust, bonding, communication, empathy, shared value dan Reciprocity) yang dinilai memiliki pengaruh positif dan signifikan terhadap loyalitas pelanggan adalah dimensi trust, bonding, shared value dan emphaty, sementara untuk dimensi communication dan Reciprocity dinlai tidak signifikan dalam analisis jalur.

\section{DAFTAR PUSTAKA}

Barnes, James G., 2003. Secrets Of Customer Relationship Management, ANDI, Yogyakarta.

Griffin, Jill. 2009. Costumer Loyalty: Menumbuhkan dan Mempertahankan. KesetiaanPelanggan.Penerbit Erlangga, Jakarta.

Kotler, Philip, dan Gary Amstrong. 2012 . Principles Of Marketing, Global Edition,. 14 Edition, Pearson Education.

Mashuri. 2008. Penelitian Verifikatif. Edisi Pertama. Yogyakarta : Andi.

Sin, L.Y.M., Tse, A.C.B., Chan, H. (2006), The Effect of Relationship Marketing Orientation on Business Performance in the Hotel Industry. Journal of Hospitality and Tourism Research, 30(4), 407-426.

Sin, L.Y.M., Tse, A.C.B., Chan, H. (2006), The Effect of Relationship Marketing Orientation on Business Performance in the Hotel Industry. Journal of Hospitality and Tourism Research, 30(4), 407-426.

Sugiyono. 2013. Memahami Penelitian Kuantitatif. Bandung: Alfabeta.

Tjiptono, Fandy. 2011, Pemasaran Jasa, Bayumedia, Malang. 